\title{
Fecal microbiota transplantation as a method to treat complications after hematopoietic stem cell transplantation
}

\author{
Maxim A. Kucher, Oleg V. Goloschapov, Ivan S. Moiseev, Boris V. Afanasyev \\ R. Gorbacheva Memorial Institute of Children Oncology, Hematology and Transplantation; Chair of Hematology, \\ Transfusiology and Transplantation, The First State I. Pavlov Medical University, St. Petersburg, Russia;
}

Dr. Maxim A. Kucher, Head, Department of Clinical Nutrition, R. Gorbacheva Memorial Institute of Children Oncology, Hematology and Transplantation; The First State I. Pavlov Medical University, St. Petersburg, Russia, L. Tolstoy St. 6-8, 197022

\section{Summary}

Allogeneic hematopoietic stem cell transplantation (allo-HSCT) is an effective method of treatment for hematological, malignant and hereditary diseases in adults and children. Despite its efficiency, HSCT is associated with several potential life-threatening complications. Mortality from bloodstream infections is the main limiting factor for HSCT. Those are caused by bacterial strains refractory to antimicrobial treatment, e.g., Clostridium difficile and Klebsiella pneumoniae, and due to immune complications, such as acute and chronic "graft versus host disease" (GvHD), which represents a conflict between donor lymphocytes and patients' tissues. In most cases, gastrointestinal tract (GIT) is primarily damaged post-HSCT, as a result of enhanced inflammation, serious diarrhea manifesting in GvHD and intestinal in-
Phone: 8 (812) 338 6260, +7 (921) 9939902

E-mail: doctorkucher@yandex.ru

\section{Gastrointestinal damage after HSCT}

Allogeneic hematopoietic stem cell transplantation (alloHSCT) is an effective method of treatment of some solid tumors, hematological, autoimmune and hereditary diseases in children and adults, which is based on providing preceding conditioning (cytostatic and/or radiation therapy) with further intravenous administration of hematopoietic stem cells, to restore bone marrow function in cases of its damage or malfunction [24].

Primary disease status at the time of therapy initiation, and degree of HLA-compatibility between the stem cell recipient

fections, in particular - pseudo-membranous colitis associated with Clostridium difficile which often occur after massive antibiotic therapy. Elimination of normal intestinal microbiota is a sufficient risk factor for GIT GvHD, pseudo-membranous colitis and antibiotic-associated diarrhea post-HSCT. Fecal microbiota transplantation (FMT) from healthy donors allows restoration of a physiological microbial variability and functional activity of intestinal microbiota leading to eradication of pathogenic microorganisms, therefore abrogating infectious complications.

\section{Keywords}

Fecal microbiota transplantation, hematopoietic stem cell transplantation, antibiotic resistance. and donor are the main factors which may predict success of allo- and haploidentical HSCT [9].

The efficacy of HSCT is limited by several main factors. First of all, primary or secondary resistance to chemotherapy confers high risk of progression or relapse of underlying disease in the posttransplant period. Second, is the frequent mortality from septic complications of nosocomial multi-drug resistant strains of bacteria, including prevalent Clostridium difficile, Klebsiella pneumonia, Pseudomonas aeruginosa and Vancomycin-resistant (VRE). Third, it is immune complications, such as acute and chronic "graft versus host" disease (GvHD), occurring due to affection of recipient tissues and organs by lymphocytes of donor origin [1]. 
GvHD pathogenesis is based on damage of recipient tissues that are recognized as antigens by immune competent cells of the donor [6]. GvHD plays a key role in post-transplantation mortality and patient's quality of life. Most susceptible tissues to damage usually have high proliferative activity, such as skin cells, enterocytes and endothelium of small bile ducts of the liver. In this case, intestinal stem cells and their niche (Paneth cells) are primary targets of intestinal GvHD, along with dysbiosis of intestinal microbiota leading to dysfunction of enterocytes, bacterial colonization and, conse- quently, potentiation of systemic inflammatory response $[18,26]$. Intestinal GvHD is manifested by symptoms of diarrhea in its secretory form. This complication is associated by morphologically seen infiltration of cytotoxic intraepithelial lymphocytes $\left(\mathrm{CD}^{+}\right)$, with damage to mucous epithelial cells of stomach and/or intestine. Appropriate histological changes can vary from lymphoid infiltration of intestinal mucosa to total destruction of crypts and formation of extensive necrotic-ulcerous defects (Fig.1) [13].
A - Mild degree
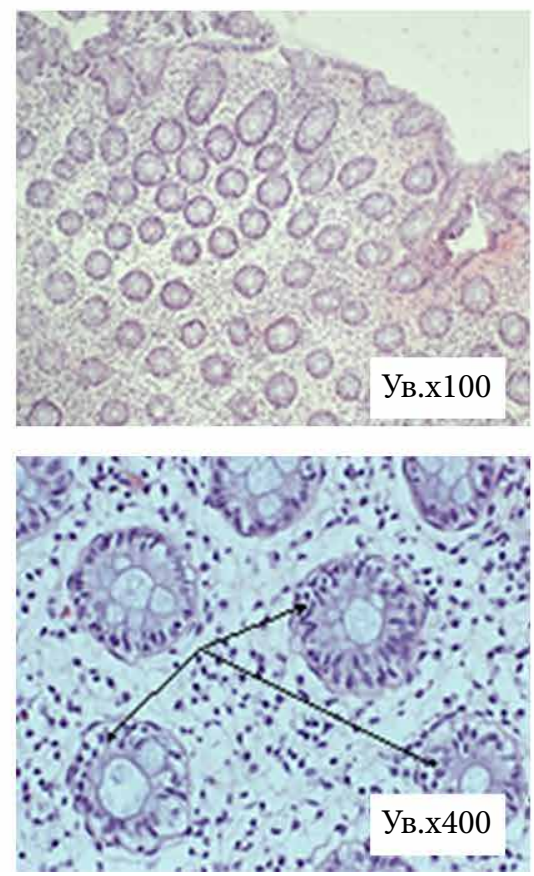

B - Medium degree
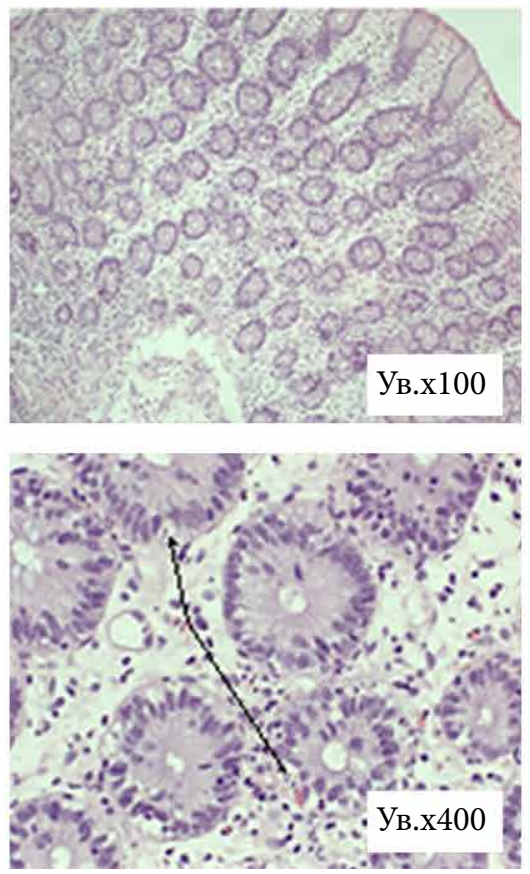

C - Severe degree
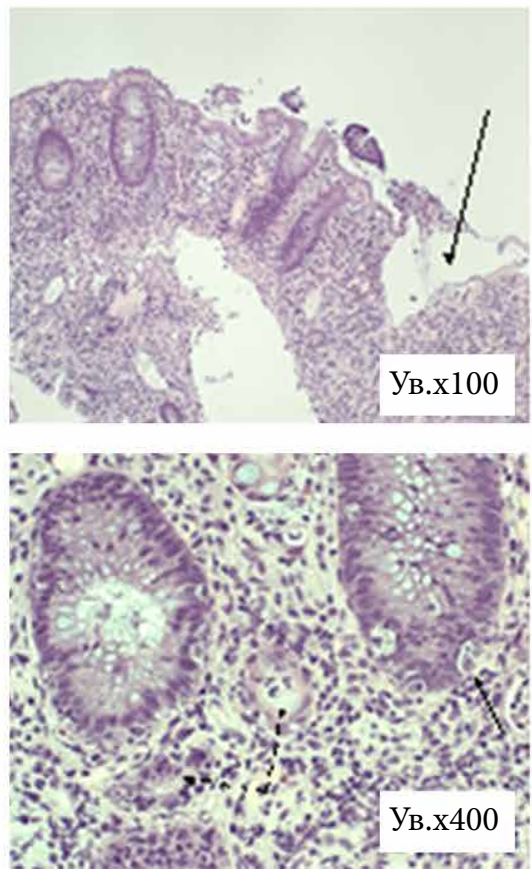

Figure 1. Histology changes in acute "graft versus host disease" of intestine [13].

A. Mild degree: focal intraepithelial lymphocytic infiltration (1-2-3 cells, arrows) in part glands with intact integrity and structure of the glands of the mucous membrane.

B. Medium degree: common uneven, often quite abundant lymphocytic infiltration with formation of nuclear foci rexis of epithelial cells (arrow) and small foci of subtotal or total destruction of some glands.

C. Severe degree: larger areas of destruction of the mucous membrane, the bottom of defects is loose immature granulation tissue (top right, arrow). Remaining glands are with symptoms of subtotal or total destruction (dotted arrows) or with nuclear rexis of epithelial cells (arrows).

In most cases, gastrointestinal tract (GIT) is a primary organ damaged, thus resulting to enhanced inflammation of immune origin, serious diarrhea, due to GvHD manifestation, and intestinal infections, in particular, pseudo-membranous colitis associated with Clostridium difficile associated with massive antibiotic therapy. Consequent elimination of normal intestinal microbiota is among main risk factors for GvHD of GIT, pseudo-membranous colitis and antibiotic-associated diarrhea after HSCT. Frequency of deaths after HSCT is known to be significantly higher in patients with skewed biodiversity of normal microbiota [11].

Intestinal damage after HSCT is clinically manifesting by a maldigestion syndrome which includes anorexia, nausea, vomiting, abdominal pain and diarrhea. These symptoms quickly lead to malfunction of intestinal barrier function, reduced adaptation reserves of the organism, development of protein-energy malnutrition and cachexia.
There are several reasons for high mortality in patients undergoing allo-HSCT. First, long period of pancytopenia which is associated with severe infection complications and requires administration of broad-spectrum antibiotics, which, in turn, leads to partial elimination or lack of normal intestinal microbiota, selection for multi-drug resistant bacterial strains, their subsequent expansion and dominance over normal microbiota (Tab. 1) [20]. Second, intensive chemotherapy and allo-HSCT in most cases leads to altered structure and decreased protective functions of intestinal wall, which is clinically expressed as mucositis which results from direct toxic effects of chemotherapy upon epithelial and vascular structures of intestine, causing invasion of pathogenic microorganisms into the intestinal wall, in the presence of neutropenia and developing GvHD. 
Table 1. Intestinal microbiota: alterations during antibiotic treatment, adapted from Peterson C. et al [20].

\begin{tabular}{|c|c|c|c|c|}
\hline Antibiotic & \multicolumn{4}{|c|}{ Alterations of microbiota } \\
\hline Name & Activity/Spectrum & Reduced diversity & Community loss & Community expansion \\
\hline Amoxicillin & $\begin{array}{l}\text { - } \beta \text {-lactam antibiotic: } \\
\text { inhibits peptidogly- } \\
\text { can synthesis } \\
\text {-extended spectrum }\end{array}$ & -Bifidobacterium & $\begin{array}{l}\text {-Lactobacillus spp., } \\
\text { Enterococcus spp., } \\
\text { Enterobacteriaceae } \\
\text { spp. }\end{array}$ & \\
\hline Vancomycin & $\begin{array}{l}\text {-glycopeptide: } \\
\text { inhibits peptidogly- } \\
\text { can cross-linkage }\end{array}$ & $\begin{array}{l}\text { Widespread reduc- } \\
\text { tions }\end{array}$ & $\begin{array}{l}\text {-Lactobacillus spp., } \\
\text { Enterococcus spp., } \\
\text { Group D Strepto- } \\
\text { coccus } \\
\text {-Bacteroidales, } \\
\text { Clostridiales } \\
\text {-Lactobacillus } \\
\text { plantarum, Faecali- } \\
\text { bacterium praus- } \\
\text { nitzii, Clostridium } \\
\text { cluster IV and XIVa, } \\
\text { Escherihia coli, } \\
\text { Haemophilus spp., } \\
\text { Serratia }\end{array}$ & $\begin{array}{l}\text {-Enterobacteriaceae } \\
\text {-Lactobacillaceae, Veruccomi- } \\
\text { crobiaceae } \\
\text {-Paenibacillaceae, Firmicutes, } \\
\text { Anaeroplasmataceae }\end{array}$ \\
\hline Ciprofloxacin & $\begin{array}{l}\text {-quinoline: } \\
\text { inhibits DNA repli- } \\
\text { cation } \\
\text {-broad spectrum }\end{array}$ & $\begin{array}{l}\text { Widespread reduc- } \\
\text { tions }\end{array}$ & $\begin{array}{l}\text {-Clostridiales, Fae- } \\
\text { calibacterium spp. }\end{array}$ & \\
\hline Cephalosporin & $\begin{array}{l}\text { - } \beta \text {-lactam antibiotic: } \\
\text { inhibits peptidogly- } \\
\text { can synthesis } \\
\text {-narrow spectrum }\end{array}$ & -Firmicutes & $\begin{array}{l}\text {-Actinobacteria } \\
\text { (Slackia and Bifido- } \\
\text { bacterium), Betap- } \\
\text { roteobacteria, } \\
\text { Streptococcus spp., } \\
\text { Eubacterium }\end{array}$ & \\
\hline
\end{tabular}

Thus, currently available drugs and technologies for treatment of infectious complications and GvHD do not solve the problem of early mortality among hematological patients after allo-HSCT. Those patients with severe damage of digestive system are at high risk of fatal outcome, due to infectious complications, metabolic disorders, massive intestinal bleeding and increasing cachexia, even if achieving complete remission of underlying malignant disease following a successful HSCT.

\section{Positive effects of directed microbiota correction}

There are conflicting reports on clinical effects of intestinal microbiota correction. Some of these approaches have, however, shown their ability to prevent complications occurring after organ and cell transplantation (Tab. 2).

Table 2. Results of gut microbial interventions upon results of cell/organ transplantation based on review by Wang et al. [29]

\begin{tabular}{|c|c|c|c|}
\hline $\begin{array}{l}\text { Transplanted } \\
\text { organ }\end{array}$ & $\begin{array}{l}\text { Intervention } \\
\text { methods }\end{array}$ & Results & $\begin{array}{l}\text { Animal/human } \\
\text { study }\end{array}$ \\
\hline \multirow{5}{*}{ Liver } & \multirow{3}{*}{$\begin{array}{l}\text { Selective diges- } \\
\text { tive decontami- } \\
\text { nation }\end{array}$} & Reducing the high incidence of infection & Human study \\
\hline & & $\begin{array}{l}\text { Gram-positive microorganisms infection predominated over } \\
\text { Gram-negative rods and anaerobes }\end{array}$ & Human study \\
\hline & & No infection prevention & Human study \\
\hline & Antibiotics & Partly ameliorating enhanced ischemia/reperfusion injury & Animal study \\
\hline & $\begin{array}{l}\text { Lactic acid bacte- } \\
\text { ria and fibers }\end{array}$ & Reducing bacterial infection rates & Human study \\
\hline
\end{tabular}




\begin{tabular}{|l|l|l|l|}
\hline $\begin{array}{l}\text { Transplanted } \\
\text { organ }\end{array}$ & $\begin{array}{l}\text { Intervention } \\
\text { methods }\end{array}$ & Results & $\begin{array}{l}\text { Animal/human } \\
\text { study }\end{array}$ \\
\hline \multirow{2}{*}{ Liver } & Only fibers & Reducing incidence of severe infections & Human study \\
\cline { 2 - 4 } & Probiotics & $\begin{array}{l}\text { Promoting partial restoration of intestinal microflora } \\
\text { and improving intestinal barrier function }\end{array}$ & Animal study \\
\cline { 2 - 4 } & Reducing the liver injury by acute rejection & Animal study \\
\hline \multirow{2}{*}{ Small bowel } & Probiotics & $\begin{array}{l}\text { Ameliorating small bowel histological injuries and reducing } \\
\text { bowel transplant }\end{array}$ & Animal study \\
\hline \multirow{2}{*}{$\begin{array}{l}\text { Hematopoietic } \\
\text { stem cells }\end{array}$} & $\begin{array}{l}\text { Total GIT } \\
\text { decontamination }\end{array}$ & Preventing acute graft-versus host disease (GVHD) & Human study \\
\cline { 2 - 4 } & Polymyxin B & Ameliorating GVHD & Animal study \\
\cline { 2 - 4 } & Probiotics & Reducing acute GVHD and improving survival & Animal study \\
\hline
\end{tabular}

\section{Human microbiota}

Human intestinal microbiota represents a broad set of obligatory and facultative microorganisms that can cause disease in case of suppressed immunity or immunological incompatibility in the host.

There are two kinds of microorganisms classified by their location in the gut: luminal microbiota, which is located in the intestine indigestible dietary fiber and mucosal, adjacent to epithelial cells of the intestine, being integrated into parietal mucin layer. Both luminal and mucosal microbiota may impact the condition of human body, due to their regulatory interactions, and perform many metabolic effects such as detoxification, suppression of pathogenic microorganisms, regulation of immune system, regeneration of epithelium, synthesis of certain vitamins and essential amino acids, fat metabolism, etc. Dominating intestinal bacteria include 5 types: Firmicutes, Bacteroidetes, Proteobacteria, Actinobacteria and Verrucomicrobia. Among them, two types of microbes (Bifidobacterium and Lactobacillus) play a crucial role in development of microbiota till the moment of birth (Tab.3).

Table 3. Intestinal microbiota diversity, by Weber et. al. [30]

\begin{tabular}{|c|c|c|c|c|c|}
\hline Phylum & Class & Order & Genus & $\begin{array}{l}\text { Gram } \\
\text { stain }\end{array}$ & $\begin{array}{l}\text { Type of } \\
\text { anaerobe }\end{array}$ \\
\hline \multirow[t]{5}{*}{ Firmicutes } & Bacilli & Bacillales & $\begin{array}{l}\text { Gemella } \\
\text { Staphylococcus }\end{array}$ & \multirow[t]{2}{*}{+} & \multirow[t]{2}{*}{ Facultative } \\
\hline & & Lactobacillales & $\begin{array}{l}\text { Enterococcus } \\
\text { Lactobacillus } \\
\text { Streptococcus }\end{array}$ & & \\
\hline & Clostridia & Clostridiales & $\begin{array}{l}\text { Blautia } \\
\text { Clostridium } \\
\text { Eubacterium } \\
\text { Faecalibacterium } \\
\text { Ruminococcus } \\
\end{array}$ & + & Obligate \\
\hline & Erysipelotrichia & Erysipelotrichiales & $\begin{array}{l}\text { Erysipelatoclostridium } \\
\text { Holdemania }\end{array}$ & + & Obligate \\
\hline & Negativicutes & Selenomonadales & $\begin{array}{l}\text { Acidaminococcus } \\
\text { Megasphaera } \\
\text { Phascolarctobacterium } \\
\text { Veillonella }\end{array}$ & - & Obligate \\
\hline Bacteroidetes & Bacteroidia & Bacteroidales & $\begin{array}{l}\text { Bacteroides } \\
\text { Prevotella }\end{array}$ & - & Obligate \\
\hline Proteobacteria & $\begin{array}{l}\text { Gammaproteo- } \\
\text { bacteria }\end{array}$ & Enterobacteriales & $\begin{array}{l}\text { Escherichia } \\
\text { Klebsiella }\end{array}$ & - & Facultative \\
\hline \multirow[t]{2}{*}{ Actinobacteria } & \multirow[t]{2}{*}{ Actinobacteria } & Actinomycetales & Actinomyces & \multirow[t]{2}{*}{+} & \multirow[t]{2}{*}{ Facultative } \\
\hline & & Bifidobacteriales & Bifidobacterium & & \\
\hline Verrucomicrobia & Verrucomicrobiae & Verrucomicrobiales & Akkermansia & - & Obligate \\
\hline
\end{tabular}


Stable composition of intestinal microbiota and regulation of local immune system reactivity are considered the key aspect for its functional activities. One should take into account of short chain fatty acids (acetate, propionate, butyrate) and antimicrobial peptides produced in situ, regulation of formation of T-regulatory cells (Treg) and IgA in bacteria from intestinal lumen. At the level of lamina propria, metabolic maintenance of transforming growth factor (TGFß), integrin $\mathrm{aE}\left(\mathrm{CD}_{103^{+}}\right)$, dendritic cells, Treg and T-helper (Th17) producing IL-10, IL-22 are important regenerative factors of epithelial cells. At the level of mesenteric lymph node, one should discuss interaction with innate lymphoid cells via a RORyt nuclear receptor, which reduces local inflammation [29]. Preservation of these interactions allows the growth suppression of pathogenic microbiota, eliminate endogenous and exogenous pathogens, maintain structural integrity of intestinal epithelium.

\section{Variability evaluation of intestinal microbiota}

Until now, qualitative identification of composed intestinal microbiota, especially anaerobic microorganisms, represents the main problem in diagnostics of many human bacteria that are undetectable by classical bacteriological methods. Implementation of fecal microbiota transplantation (FMT) procedure into clinical practice and its scientific rationale were largely possible due to development of the microbe identification methods by genome next-generation sequencing (NGS) of bacterial DNAs, and, to a lesser extent, by multiplex real-time polymerase chain (e.g. Colonoflor-16) [8]. Development of the s.c. shotgun next-generation sequencing based on differential analysis of bacterial $16 \mathrm{~S}$ ribosomal RNA and identification of distinct molecular isolates allowed precise DNA profiling of microbiota composition from donor and recipient, therefore, characterizing the most appropriate fecal donors, and evaluating microbiological results of the treatment [16]. This sequencing procedure consists of 4 successive stages: selection of microbial DNAs from feces, amplification by PCR V4-5 plots of the 16S rRNA gene, sequencing, comparing individual results with a database of previously studied samples, for example, from the NCBI Sequence Read Archive database.

Quantitative 16S RNA analysis in patients with sepsis has revealed sufficient shifts of the main microbial types in the stool samples from the intensive care patients [34]. The workers observed scewed diversity of main microbial communities ( 1 to 4 bacterial taxa) in $30 \%$ of the patients. Bacteria associated with the genera Enterococcus and Staphylococcus and the family Enterobacteriaceae comprised the majority of these communities.

As seen from the Figure 2, normal stool specimens $(\mathrm{H} 1, \mathrm{H} 2$, H3, H4, and H5) were characterized by prevalence of Firmicutes and, in most cases, Bacteroidetes, without Proteobacterial abundance (Fig 2. 1A). In a half of ICU patients (ICU1, ICU4, ICU6, ICU9, ICU11, and ICU15), either Proteobacteria or Firmicutes organisms were totally dominant from at least one time point of stool collection (Fig. 1B and C).
In ICU1, ICU11, and ICU15, the authors observed drastic changes in microbial ratios, with Firmicutes being completely replaced by Proteobacteria. The latter phylum predominated also in most stool samples of the patients ICU6 (Fig 2. 1B) and ICU4 (Fig 2. 1C).
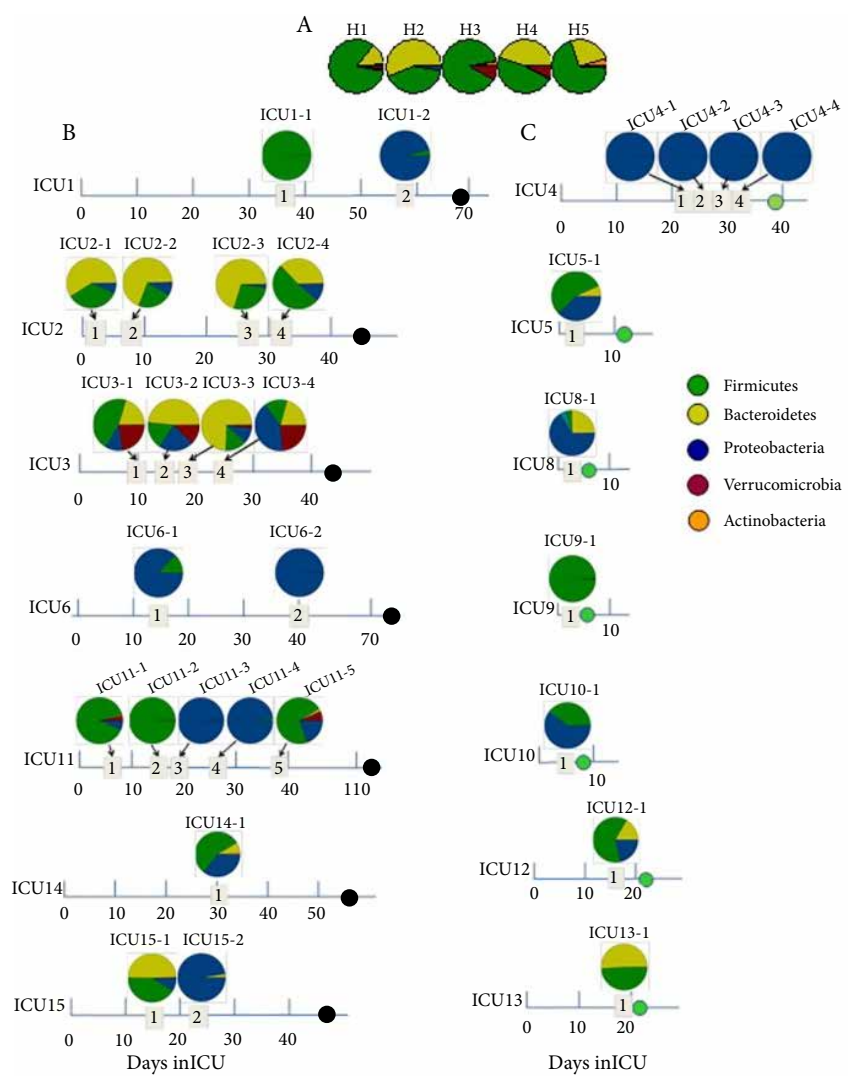

Figure 2. Composition of the gut microbiome at the phylum level determined by molecular analysis of stool samples collected from healthy controls (A), deceased ICU patients with severe sepsis (black circles on the time line) (B), and recovered ICU patients (green circles) (C). Dates of stool collection are displayed in numbered quadrants [34].

Hence, the gross shifts in microbial composition in critically ill patients with clinical signs of sepsis are, mainly, unidirectional, leading to exhaustion of large microbial philae. However, these changes seem to be quite heterogenous and need further clarification for bacterial types associated with worse clinical prognosis.

Under common clinical conditions, however, diagnostics of bacterial dysbiosis is performed for planning different therapeutic measures, including clinical FMT effects. Evaluation of gastrointestinal microflora and mucosa is, generally, performed by means of the following microbiological methods: - conventional bacteriological tests (microscopy, seeding, assessment of antibiotic resistance).

- biopsy of stomach and/or intestine mucosa with subsequent histology and immunophenotyping of local lymphocytes; verification of infectious lesions at the intestinal mucosa;

- definition of Clostridium difficile toxin A and B in stool;

- fecal calprotectin in stool etc. 


\section{Fecal microbiota transplantation}

In the recent years, FMT was actively developing as a method to restore functional and anatomical integrity of intestinal microbiota in appropriate clinical situations (Fig.3) $[12,14,21$,$] .$

Typical changes of intestinal microbiota in inflammatory bowel diseases include reduced diversity of obligate microorganisms, especially, deficiency of Firmicutes and Bacteroidetes [3]. Ultimately, this leads to lack of butyrate synthesis by Faecalibacterium prausnitzii. This metabolite is a local anti-inflammatory agent, acting via IL-8 inhibition [25].

The main known mechanisms of FMT action include competition for nutrients, direct inhibition of excessive pathogen growth, modulation of host immune system by interaction with normal microbiota. FMT seems to be more effective, than use of probiotic preparations, in restoring altered intestinal microbiota, since the latter is unable to colonize intestinal space for an extended period.

FMT also allows correction of both microbiota in digestive ways, and microbial spectrum of other body areas (mouth, lungs, urinary routes, etc.) to less pathogenic species which are more sensitive to antibiotics. This effect can be used to eradicate antibiotic-resistant pathogenic bacteria strains based on natural competition and antagonism between the microorganisms [8].
In 2014, a meta-analysis of clinical studies showed that FMT was effective in $87 \%$ of diarrhea cases (a total of 536 patients) caused by Clostridium difficile, with primary resistance to prior therapy with metronidazole and vancomycin [2]. The transplant administration route was an important factor affecting treatment outcomes, i.e., the microflora delivery to the stomach yielded $81 \%$ of clinical success; to duodenum, $86 \%$; via ascending part of the colon (with fibrocolonoscopy), $93 \%$ response; to descending colon by means of deep enema, $84 \%$ of successful treatment .

A subsequent review article discussed 45 clinical studies (112 patients), showing ambiguous FMT efficiency in inflammatory bowel disease, i.e., only 0 to $68 \%$ of the patients achieved clinical remission [22]. The authors noted that possible failure of FMT could be connected, on the one hand, with poor state of donor's microbiota, especially, reduced microbial diversity. On the other hand, severe malfunction of patient's GIT with high values of the Mayo scores could also influence the outcomes.

The attempts of clinical FMT implementation are carried out not only in clinical conditions related to intestinal infections, but also presumed irregularities between altered microbiota and immune system imbalance, such as irritable bowel syndrome, rheumatoid arthritis, diabetes type 2, autism, chronic fatigue syndrome, multiple sclerosis and Parkinson's disease [5]. There are single reports on FMT performed in order to treat sepsis with multiple organ dysfunction syndrome, and to eliminate vancomycin-resistant bacteria [32]

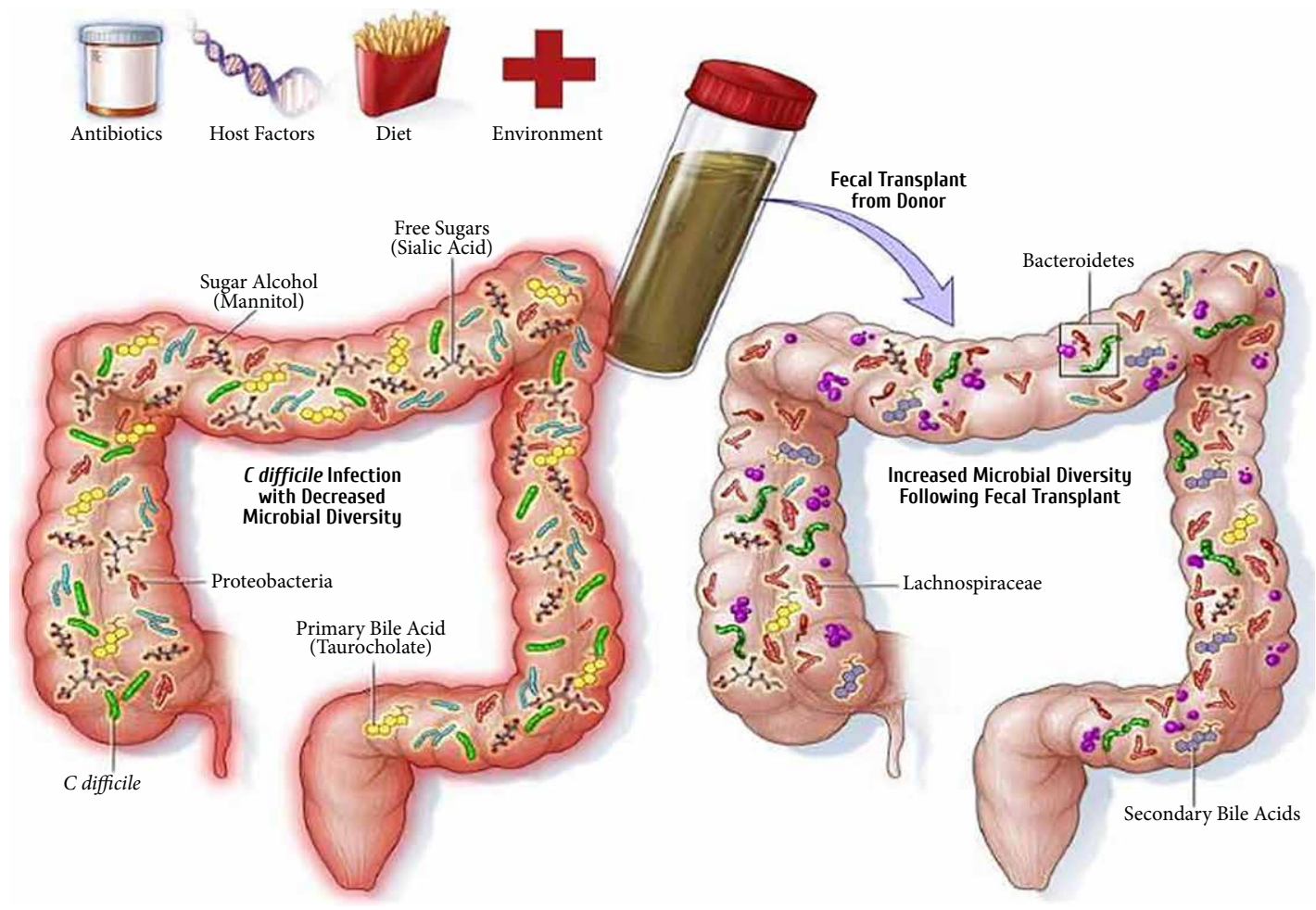

Figure 3. Fecal microbiota transplantation scheme [15]. 
Increasing number of clinical research reporting successful outcomes of FMT in various diseases is accompanied by arrangement of the first specialized biobank in 2012. This USA-based facility was established for storage of fecal samples for FMT. Currently, the biobank is linked to more than 750 clinics at all the 50 USA states providing an opportunity for a constant access to the samples of donor fecal microbiota. The method was adopted and regulated by the US Food and Drug Administration (FDA). In 2013, this body has approved FMT as a therapeutic method for treatment of refractory infections associated with Clostridium difficile, for controlled clinical studies ("policy with respect to the investigational new drug requirements for use of fecal microbiota transplantation to treat Clostridium difficile infection not responding to standard treatment") [27].

On the basis of clinical research, FMT was included to the Guidelines issued by European Society of Clinical Microbiology and Infectious Diseases (ECMID) concerning treatment of vancomycin-resistant (VRE) infections caused by Clostridium difficile, at the AI level of evidence [4]. However, infections associated with Clostridium difficile, are just among potential indications for the FMT usage. Similarly, the FMT use was approved by the European Crohn's and Colitis Organization as an approach to treatment of chronic nonspecific inflammatory bowel diseases [21].

Similarly, FMT can significantly modulate immune function and have positive effects on other GIT inflammatory processes of immune origin, in particular, resistant graft-versushost-disease GvHD of intestine. In fact, several researchers confirm that preventive use of FMT leads to a decreased risk of infectious complications during treatment of hematological diseases [16].

Despite some encouraging results of FMT-assisted treatment, it is still rarely used in severely immunocompromised patients, e.g., after alloHSCT. This may be due to low performance status of HSCT recipients, severely damaged gastrointestinal mucosa associated with infectious complications and risk of microbial dissemination with a transplanted donor microbiota. However, it is important to mention, that the transplanted microorganisms potentially substitute multi-drug resistant flora due to natural antagonism and improve the control over infectious complications with standard antibiotics.

\section{Donor selection and transplant delivery of fecal microbiota}

Optimal donor selection for FMT is still an uncertain aspect in FMT implementation. Some medical, ethical and economic issues should be resolved, e.g., which kind of graft will be indicated in certain cases, either being related, unrelated or autologous. From economic and ethical viewpoints, an optimal solution is to use autologous source of transplant. However, qualitative composition of a patient's microbiota is often changed dramatically after previous courses of chemoand antibiotic therapy. Allogeneic donors may be found among healthy relatives: mother, father, siblings. However, "healthy" donor is not yet proven to be the best option for HSCT patient. Development of relevant biobanks will help to resolve the problem of a donor search/selection.

To perform a successful FMT, it is necessary to follow several factors. First of all, an accurate donor selection, must match, on the one hand, classical infectious requirements for allogeneic donor, and should not have any GIT comorbidities or oncologic diseases. On the other hand, the transplant should possess a normally present, diverse intestinal microbiota free of certain virulent pathogens. The standard technology of graft preparation should be used. Is it well developed and tested depending on the form of its delivery, and necessity of long-term storage [28].

Another important factor determining efficiency depends on the transplant delivery route. Currently, there are several options: introduction of donor microbiota to the upper GIT by means of oral capsules; bringing it to the stomach via a gastroscope channel; microbiota delivery to duodenal space with a nasointestinal tube or PEG gastrostomy; delivery to colon, using deep enema, or by means of colonoscopy [33]. Each method has its indications and advantages but, from the point of "engraftment" probability, a multiple delivery to the coecal region by means of colonoscopy is now considered to be the most effective approach (93\%). The delivery technologies evolve continuously, aiming at both improving efficiency and increasing patient comfort. E.g., transendoscopic delivery to the cecum with pin-assisted tube fixation, and use of oral capsules are the most promising procedures now [19]. Another important question is the necessity of anesthesia upon delivery of donor's transplant. In our opinion, the use of medical sedation is required not only for children, but in adults as well, for ethical reasons and better compliance.

Of the new trends, different methods of preparing matrices for transplanted microorganisms should be mentioned, for example, usage of pectin carriers, to increase fermentation activity of the dietary fibers, with synthesis of short chain fatty acids, thus allowing faster multiplication of the donor microorganisms [31].

\section{Features of fecal microbiota transplantation in hematopoietic stem cell transplantation}

Allo-HSCT negatively influences patient's normal microbiota, due to a number of specific factors, e.g., low-microbial diets, often leading to the development of malnutrition; intestinal decontamination associated with eradication of obligate microorganisms, application of cytotoxic drugs and/ or radiation that damage GIT epithelial cells. Along with antibiotic therapy, the above factors lead to severe alterations of bacterial microbiota, development of pathogenic multidrug-resistant microbiota, presumably increasing the risk of acute GvHD [10, 23]. 
Worldwide clinical experience shows, that GvHD of intestine treatment with basic immunosuppressive drugs of different generations is often insufficient to prevent excessive inflammatory response and relief of a diarrhea syndrome. Systemic antibiotic therapy, oral decontamination with non-absorbable antibiotics is ineffective for a significant number of patients with detectable colonization with Clostridium difficile. Up to $40 \%$ of patients with infection associated with Clostridium difficile, are resistant to metronidazole or vancomycin therapy [7]. Massive use of antibiotics post-HSCT leads to significant disturbances of intestinal microbiota homeostasis, whereas use of probiotic bacterial formulae may be ineffective due to their inability to colonize the intestinal spaces for an extended time period.

According to our data, diarrhea after allo-HSCT is observed in $79 \%$ of cases and can persist for several months, thus eventually leading to development of cachexia and lethal infectious complications. At the R. Gorbacheva Memorial Institute for Children Oncology, Hematology and Transplantation, we have a successful experience of FMT in four patients after allo-HSCT - adults $(n=2)$ and children $(n=2)$ with prolonged severe diarrheal syndrome, due to immune and infectious complications [8].

Hence, the general idea of using FMT in HSCT looks promising in many aspects: prevention and treatment of infectious complications, prophylaxis of a malabsorption syndrome, and prevention of cachexia, as well as the treatment of steroid-resistant intestinal forms of acute GvHD [12].

\section{Conclusion}

A significantly decreased survival is observed in cases of post-HSCT infectious complications resistant to standard antimicrobial therapy, due to increasing mortality caused by septic conditions, usually associated with pathogenic microorganisms: Klebsiella pneumoniae, Pseudomonas aeruginosa, Clostridium difficile, Acinetobacter baumannii. Prolonged antibiotic therapy seems to be a key factor leading to multi-drug resistance of some gut bacteria which in turn, may be a trigger to a severe GvHD. Development of intestinal GvHD in most cases leads to the inability of adequate nutrition, along with a maldigestion and malabsorption syndrome, which ultimately leads to protein-energy malnutrition, cachexia and reduced quality of life. Both in sepsis and GvHD, severe changes are observed in qualitative composition and ratios of microbiota living in human gut and other areas of the body.

Initial clinical experience with effective and safe FMT treatment in heavily pretreated category of patients allows to consider this method complementary additional or, in some cases, an alternative technology of therapy for infectious and immune complications after allo-HSCT. FMT results into changes of intestinal microbiota composition, which may help to eradicate multi-drug resistant gut infections, e.g., Clostridium difficile, Klebsiella pneumoniae, to reduce antibiotic-associated diarrhea, to replace resistant bacterial species in other areas of the body, and to change microbial profile to a less-virulent landscape.
Further implementation of FMT in clinical practice requires a detailed study, including optimization of criteria for the therapy initiation, selection of the most matched donors by means of multiplex DNA diagnostics, or next-generation DNA sequencing of microbiota, evaluation of long-term efficacy and safety of the transplants.

\section{Conflict of interests}

The authors have no conflict of interest to declare.

\section{References}

1. Afanasyev BV, Zubarovskaya LS, Moiseev IS. Allogeneic hematopoietic stem cell transplantation in children: state of art, issues and prospects. Russian Journal of Children Hematology and Oncology 2015;2(2); 28-42 (In Russian).

2. Cammarota G, Ianitro G, Gasbarrini A. Fecal microbiota transplantation for the treatment of Clostridium difficile infection. A systematic review. J Clin Gastroenterol 2014; 48(Suppl 1):80-84.

3. Damman CJ, Miller SI Surawicz C.M, Zisman TL. The microbiome and inflammatory bowel disease: is there a therapeutic role for fecal microbiota transplantation? Am J Gastroenterol 2012;107:1452-1459.

4. Debast SB, Bauer MP, Kuijper JL. European society of clinical microbiology and infectious diseases: update of the treatment guidance document for Clostridium difficile infection. Clin Microbiol Infect 2014; 20(2):1-26.

5. Evrensel A. Fecal microbiota transplantation and its usage in neuropsychiatric disorders. Clin Psychopharmacol Neurosci 2016;14(3): 231-237.

6. Ferrara JL, Levine JE, Reddy P, Holler E. Graft-versushost-disease. Lancet 2009; 373(9674): 1550-1561.

7. Gallo A, Passaro G, Gasbarrini A, Landolfi R, Montalto M. Modulation of microbiota as treatment for intestinal inflammatory disorders: an up-to-date. World J Gastroenterol 2016; 22(32): 7186-7202.

8. Goloschapov OV, Kucher MA, Suvorova MA, Klementeva RV, Shcherbakov AA, Shvetcov AN, Moiseev IS, Chukhlovin AB, Afanasyev BV. First experience of treatment for multidrug resistant infectious complications associated with Clostridium difficile and Klebsiella pneumoniae with fecal microbiota transplantation in patients after allogeneic hematopoietic stem cell. Infekzionnye Bolezni 2017; 15(2) In press (In Russian).

9. Gratwohl A, Baldomero H, Schwendener A, Gratwohl M, Apperley J, Frauendorfer K, Niederwieser D. The EBMT activity survey 2008: impact of team size, team density and new trends. Bone Marrow Transplant 2011;46: 174-191.

10. Jenq RR, Ubeda C, Taur Y, Menezes CC, Khanin R, Dudakov JA, Liu C, West ML, Singer NV, Equinda MJ, Gobourne A, Lipuma L, Young LF, Smith OM, Ghosh A, Hanash AM, Goldberg JD, Aoyama K, Blazar BR, Pamer EG, van den Brink MR. Regulation of intestinal inflammation by microbiota following allogeneic bone marrow transplantation. J Exp Med 2012; 209; 903-911. 
11. Jenq RR, Taur Y, Devlin SM, Ponce DM, Goldberg JD, Ahr KF, Littmann ER, Ling L, Gobourne AC, Miller LC, Docampo MD, Peled JU, Arpaia N, Cross JR, Peets TK, Lumish MA, Shono Y, Dudakov JA, Poeck H, Hanash AM, Barker JN, Perales MA, Giralt SA, Pamer EG, van den Brink MR. Intestinal Blautia is associated with reduced death from graftversus-host disease. Biol Blood Marrow Transplant 2015; 21(8):1373-1383.

12. Kakihana K. Fecal microbiota transplantation for patients with steroid-resistant acute graft-versus-host disease of the gut. Blood 2016; 128(16):2083-2088.

13. Kucher MA, Pirogova OV, Goloschapov OV, Karev VE, Shvetcov AN, Afanasyev BV. Specificities of complex nutritive support of patients with cytostatic therapy and haemopoietic stem cell transplantation. Voprosy Dietologii 2016;6(1):5-12. (In Russian).

14. Leszczyszyn JJ, Radomski M, Leszczyszyn AM. Intestinal microbiota transplant - current state of knowledge. Reumatologia. 2016;54(1):24-28.

15. Medscape 2015 (Gastroenterology, AGA Institute) http:// img.medscape.com/article/849/384/849384-fig1.jpg

16. Montassier E, Al-Ghalith GA, Ward T, Corvec S, Gastinne T, Potel G, Moreau P, Cochetiere M, Batard E, Knights D. Pretreatment gut microbiome predicts chemotherapy-related bloodstream infection. Genome Med 2016; 8(1):49.

17. Moore-Connors JM, Dunn KA, Bielawski JP, Van Limbergen J. Novel strategies for applied metagenomics. Inflamm Bowel Dis 2015; 22:709-718.

18. Nalle SC, Turner JR. Intestinal barrier loss as a critical link between inflammatory bowel disease and graft-versushost disease. Mucosal Immunol 2015; 8(4):720-730.

19. Peng Z, Xiang J, He Z, Zhang T, Xu L, Cui B, Li P, Huang G, Ji G, Nie Y, Wu K, Fan D, Zhang F. Colonic transendoscopic enteral tubing: A novel way of transplanting fecal microbiota. Endoscopy International Open. 2016; 4(6): E610E613.

20. Peterson C, Round JL. Defining dysbiosis and its influence on host immunity and disease. Cell Microbiol 2014;16(7):1024-1033.

21. Rahier JF, Magro F, Abreu C, Armuzzi A, Ben-Horin S, Chowers Y, Cottone M, de Ridder L, Doherty G, Ehehalt R, Esteve M, Katsanos K, Lees CW, Macmahon E, Moreels T, Reinisch W, Tilg H, Tremblay L, Veereman-Wauters G, Viget N, Yazdanpanah Y, Eliakim R, Colombel JF. Second European evidence-based consensus on the prevention, diagnosis and management of opportunistic infections in inflammatory bowel diseases. J Crohns Colitis 2014; 8:443-468.

22. Rossen NG, McDonald JK, deVries EM, D’Haens GR, de Vos WM, Zoetendal EG, Ponsioen CY. Faecal microbiota transplantation as novel therapy in gastroenterology: A systematic review. World J Gastroenterol 2015; 21:5359-5371.

23. Shono Y. Intestinal microbiota related effects on graft versus host disease. Int J Hematol 2015; 101; 428-437.
24. Slavin, S. New strategies for bone marrow transplantation. Curr Opin Immunol 2000; 12: 542-551.

25. Sokol H. Faecalibacterium prausnitzii is an anti-inflammatory commensal bacterium identified by gut microbiota analysis of Crohn disease patients. Proc Nat Acad Sci USA 2008; 105(43): 16731-16736.

26. Teshima T, Reddy P, Zeiser R. Acute graft-versus-host disease: novel biological insights. Biol Blood Marrow Transplant 2016; 22(1):11-16.

27. U.S. Food and Drug Administration. Guidance for Industry. Enforcement policy regarding investigational new drug requirements for use of fecal microbiota for transplantation to treat Clostridium difficile infection not responsive to standard therapies. Dept Health and Human Services, July 2013. http://www.fda.gov/BiologicsBloodVaccines/ GuidanceComplianceRegulatoryInformation/Guidances/ Vaccines/ucm 361379.htm

28. van Nood E, Speelman P, Kuijper EJ, Keller JJ. Struggling with recurrent Clostridium difficile infections: is donor faeces the solution? Eurosurveillance 2009; 14(34):1-6.

29. Wang W, Xu S, Ren Z, Jiang J, Zheng S. Gut microbiota and allogeneic transplantation. J Transl Med 2015; 13(275): $2-11$.

30. Weber D., Jenq R., Hiergeist A., Oefner P., Dettmer K., Weber M., Koestler J., Gessner A., Taur Y., van den Brink M., Pamer E., Wolff D., Hahn J., Herr W., Holler E. Early systemic broad spectrum antibiotic treatment increases risk of graft versus host disease and treatment-related mortality after allogeneic stem cell transplantation - possible role of indirect effects by microbiome disruption. Bone Marrow Transplant 2016; 51(1): 3-4.

31. Wei Y. Pectin enhances the effect of fecal microbiota transplantation in ulcerative colitis by delaying the loss of diversity of gut flora. BMC Microbiol 2016; 16: 1-9.

32. Wei Y. Successful treatment with fecal microbiota transplantation in patients with multiple organ dysfunction syndrome and diarrhea following severe sepsis. Critical Care 2016; 20: 332 .

33. Youngster I. Oral, frozen fecal microbiota transplant (FMT) capsules for recurrent Clostridium difficile infection. BMC Medicine 2016; 14:134.

34. Zaborin A, Smith D, Garfield K, Quensen J, Shakhsheer B, Kade M, Tirrell M, Tiedje J, Gilbert JA, Zaborina O, Alverdy JC. Membership and behavior of ultra-low-diversity pathogen communities present in the gut of humans during prolonged critical illness. MBio 2014; 5(5): e01361-14. 


\title{
| Трансплантация фекальной микробиоты, как метод лечения осложнений после трансплантации гемопоэтических стволовых клеток
}

\author{
Максим А. Кучер, Олег В. Голощапов, Иван С. Моисеев, Борис В. Афанасьев \\ НИИ детской онкологии, гематологии и трансплантологии им. Р. М. Горбачевой, Кафедра гематологии, трансфузиологии \\ и трансплантологии, Первый Санкт-Петербургский государственный медицинский университет им. И. П. Павлова, \\ Санкт-Петербург, Россия
}

\section{Резюме}

Аллогенная трансплантация гемопоэтических стволовых клеток (ТГСК) - радикальный метод лечения онкогематологических и наследственных заболеваний у взрослых и детей. Несмотря на свою эффективность, ТГСК ассоциирована со значительным числом жизнеугрожающих осложнений. Главные причины неудачи лечения - это летальность от септических осложнений, вызванных нозокомиальными поли- и панрезистентными штаммами бактерий, среди которых превалирует Clostridium difficile и Klebsiella pneumoniae, и иммунных осложнений, таких как острая и хроническая реакция «трансплантат против хозяина» (РТПХ), в основе которой лежит поражение органов пациента лимфоцитами донора. В большинстве случаев первичным органом-мишенью является желудочно-кишечный тракт (ЖКТ) в результате развития неконтролируемого воспаления и тяжелой диареи при РТПХ, а также кишечных инфекций, в частности - псевдомембранозного колита ассоциированного с Clostridium difficile на фоне массивной антибиотикотерапии.
Одним из основных факторов риска развития РТПХ с вовлечением ЖКТ, псевдомембранозного колита и антибиотико-ассоциированной диареи после ТГСК считают элиминацию нормальной микробиоты кишечника. Трансплантация фекальной микробиоты (ТФМ) здорового донора позволяет восстановить физиологическое микробное разнообразие и функциональную активность микробиоты кишечника и может приводить к эрадикации патогенных микроорганизмов, тем самым купируя инфекционные осложнения.

\section{Ключевые слова}

Трансплантация фекальной микробиоты, трансплантация гемопоэтических стволовых клеток, антибиотикорезистентность. 